\title{
PENGARUH KEMUDAHAN TERHADAP KEPUTUSAN PEMBELIAN \\ MAKANAN SECARA ONLINE PADA MAHASISWA \\ (Studi kasus mahasiswa UBSI Salemba 45 Jakarta)
}

\author{
Panji Suratriadi, Jaka Santosa, Agus Suhaila \\ Universitas Bina Sarana Informatika Jakarta \\ suratriadi@gmail.com
}

\begin{abstract}
Abstrak : Kemajuan teknologi di bidang internet semakin maju dan murah, harga smartphone dan biaya pulsa internet pun semakin murah. konsumen dalam berbelanja khususnya makanan tinggal memilih makanan dan toko penjual yang ada di internet. Ditambah lagi jasa pengantar barang seperti gojek atau grab yang biayanya lebih murah, cepat, dan mudah dalam memesannya melalui internet. Begitu juga transaksi pembayaran pun semakin mudah, dengan internet banking dan pembayaran secara online di minimarket seperti indomaret dan alfamart membuat transaksi jual beli semakin cepat bahkan dalam hitungan menit saja. Dengan kemudahan dalam belanja online maka mahasiswa sebagai salah satu konsumen sering melakukan pembelian makanan secara online. Setelah dilakukan penelitian dengan motede kuantitatif dengan sampel 91 mahasiswa maka didapat hasil pengujian. Hasil uji regresi linear didapat nilai R koefisien korelasi sebesar 0,603, artinya pengaruh variabel X Kemudahan terhadap variabel Y Keptusan Pembelian Secara Online cukup kuat. Dan didapat nilai R square 0,364 artinya bahwa variabel $\mathrm{X}$ Kemudahan memiliki kontribusi mempengaruhi variabel $\mathrm{Y}$ Keputusan Pembelian Secara Online sebesar 36,40\% sisanya dipengaruhi oleh faktor faktor lain seperti kualitas produk, harga, dan lain lain.. Hasil uji Anova siginificansi linearitas (Sig) dengan syarat Sig $<0,05$ didapat hasil Sig 0,000, dengan $\mathrm{F}$ hitung 50,912 dengan demikian model persamaan regresi berdasarkan data penelitian adalah Signifikan. Hasil perhitungan regresi sederhana didapat nilai koefisien konstanta sebesar 4,515 dan variabel $\mathrm{X}$ adalah 0,788 sehingga persamaan regresinya $\mathrm{Y}=0,788 \mathrm{X}+4,515$ maka setiap kenaikan satu satuan variabel akan menyebabkan kenaikan kemudahan 0,788 . Hasil Uji didapat nilai $t$
\end{abstract}


hitung adalah 7,135 dengan nilai signifikansi 0,000 dimana nilai t Tabel dengan df $=\mathrm{n}-\mathrm{k}$ atau $\mathrm{df}=91-2, \mathrm{df}=89$ dengan signifikansi 0,05 nilai t Tabelnya adalah 1,98698. Maka 7,135 > 1,98698 berarti H0 ditolak dan H1 diterima artinya Ada pengaruh kemudahan terhadap keputusan pembelian makanan secara online pada mahasiswa.

\section{Kata Kunci: Keputusan Pembelian, Online, Mahasiswa}

\section{Pendahuluan}

Kemajuan teknologi di bidang internet semakin maju dan murah, Teknologi internet saat ini sudah dapat diakses melalui telpon pintar (smart phone) dan kacanggihan telpon pintar setiap waktu terus berubah semakin canggih sehingga biaya koneksi internet semakin hemat dan murah (detik.com). Dampak dari kemajuan teknologi dibidang internet dan smart phone berdampak kepada kehidupan masyarakat di segala bidang. Bidang ekonomi misalnya, dimana saat ini transakasi jual beli barang dan jasa semakin mudah dan cepat.

Dampak dari kemajuan teknologi internet membuat konsumen tidak lagi harus datang ke tempat atau toko si penjual, konsumen tinggal memilih toko penjual yang ada di internet dan memilih barang yang diinginkan cara belanja ini disebut juga dengan belanja secara online, Jarak antara konsumen dan penjual tidak lagi menjadi masalah dikarenakan juga ada jasa pengantar barang yang biayanya lebih murah, cepat, dan mudah dalam memesannya melalui internet. Sehingga konsumen dimudahkan dalam berbelanja dan memperoleh barang yang mereka inginkan.

Berkembangnya dunia belanja online (e-commerce) di indonesia juga ditunjang dengan kemudahan pembayaran. Perbankan juga memberikan kemudahan pembayaran dengan layanan transaksi perbankan lewat internet (internet banking.) dan juga automatic teller machine (ATM). Toko-toko retail modern (minimarket) seperti Indomaret dan Alfamart ikut memberikan layanan transaksi pembayaran secara online. Adanya internet banking dan pembayaran secara online membuat transaksi jual beli semakin cepat bahkan dalam hitungan menit saja. Sehingga belanja barang melalui internet (online) dapat dilakukan diamana pun cepat dan mudah. 
Mahasiswa merupakan salah satu bagian dari masyarakat yang juga sering melakukan belanja, diantaranya belanja kuliner melalui internet (online). Mahasiswa lebih cepat beradaftasi dengan dunia teknologi khususnya internet, Aktivitas mahasiswa dalam belajar maupun bersosialisasi di kampus maupun di luar kampus yang tinggi dan gaya hidup modern menjadikan mahasiswa menginginkan kebutuhannya segera dapat dipenuhi secara cepat dan tepat, termasuk keinginannya akan makanan dan minuman.

\section{Tinjauan Pustaka}

Pada umumnya konsumen dalam membeli barang akan melalui proses pembelian, begitu juga mahasiswa dalam membeli makanan. Menurut Howard dan Shay (dalam Basu Swastha Dharmesta,1998) proses pembelian akan melalui 5 tahapan:

1. Pemenuhan kebutuhan (need)

2. Pemahaman Kebutuhan (recognition)

3. Proses mencari barang (search)

4. Proses evaluasi (evaluation)

5. Pengambilan keputusan pembelian (decision)

Setelah melalui proses tahapan pembelian terakhir adalah melakukan keputusan pembelian. Dimana pembelian adalah sebagai pemilikan suatu tindakan dari dua atau lebih pilihan alternatif (Sumarwan,2003). Keputusan pembelian menurut Kotler \& Amstrong (2001) adalah tahap didalam proses pengambilan keputusan dimana konsumen sungguh sungguh melakukan pembelian.

Mahasiswa menurut Siswoyo (2007) didefinisikan sebagai individu yang sedang menuntut ilmu di perguruan tinggi baik negeri maupun swasta atau lembaga lain yang setingkan dengan perguruan tinggi. Pembelian makanan maupun minuman secara online menjadi ketertarikan mahasiswa dikarenakan kemudahan penggunaan teknologi internet untuk bertransaksi. Sehingga kemudahan penggunaan merupakan kepercayaan individu dimana jika mereka menggunakan sistim tertentu maka akan terbebas dari suatu upaya (Mathieson,1991). Kemudahan penggunaan bisa diartikan penggunaan sistim 
teknologi internet sebagai sistim tertentu. Dimana dalam perdagangan (ecommerce) atau belanja online membebaskan penjual dan pembeli untuk datang bertemu muka, dan datang ke bank melakukan pembayaran. Menurut Mujiyana dan Elissa (2013), belanja online adalah proses dimana konsumen secara langsung membeli barang-barang, jasa dan lain-lain dari seorang penjual secara interaktif dan real-time melalui media perantara internet.

Penelitian sebelumnya yang dilakukan oleh Wardoyo dan Intan Andini mengenai faktor- faktor yang berpengaruh terhadap keputusan pembelian secara online pada mahasiswa Universitas Gunadarma, mengatakan bahwa faktor-faktor yang mempengaruhi seseorang belanja online adalah :

1. Belanja online

2. Gaya hidup

3. Kepercayaan

4. Kemudahan

5. Kualitas Informasi

Menurut Jogiyanto (2007) indikator dari variabel kemudahan adalah mudah dipahami, mudah dipelajari, simple, dan mudah pengoperasiannya.

Sehingga dari uraian diatas dapat disimpulkan bahwa sistim internet merupakan sistim penghubung yang memudahkan antara pelaku ekonomi yaitu konsumen, penjual, perbankan dan jasa kurir (antar) dengan menggunakan teknologi internet tanpa harus bertemu muka. Sehingga dapat digambarkan dalam bagan di bawah ini: 
Bagan transaksi pembelian makanan secara online
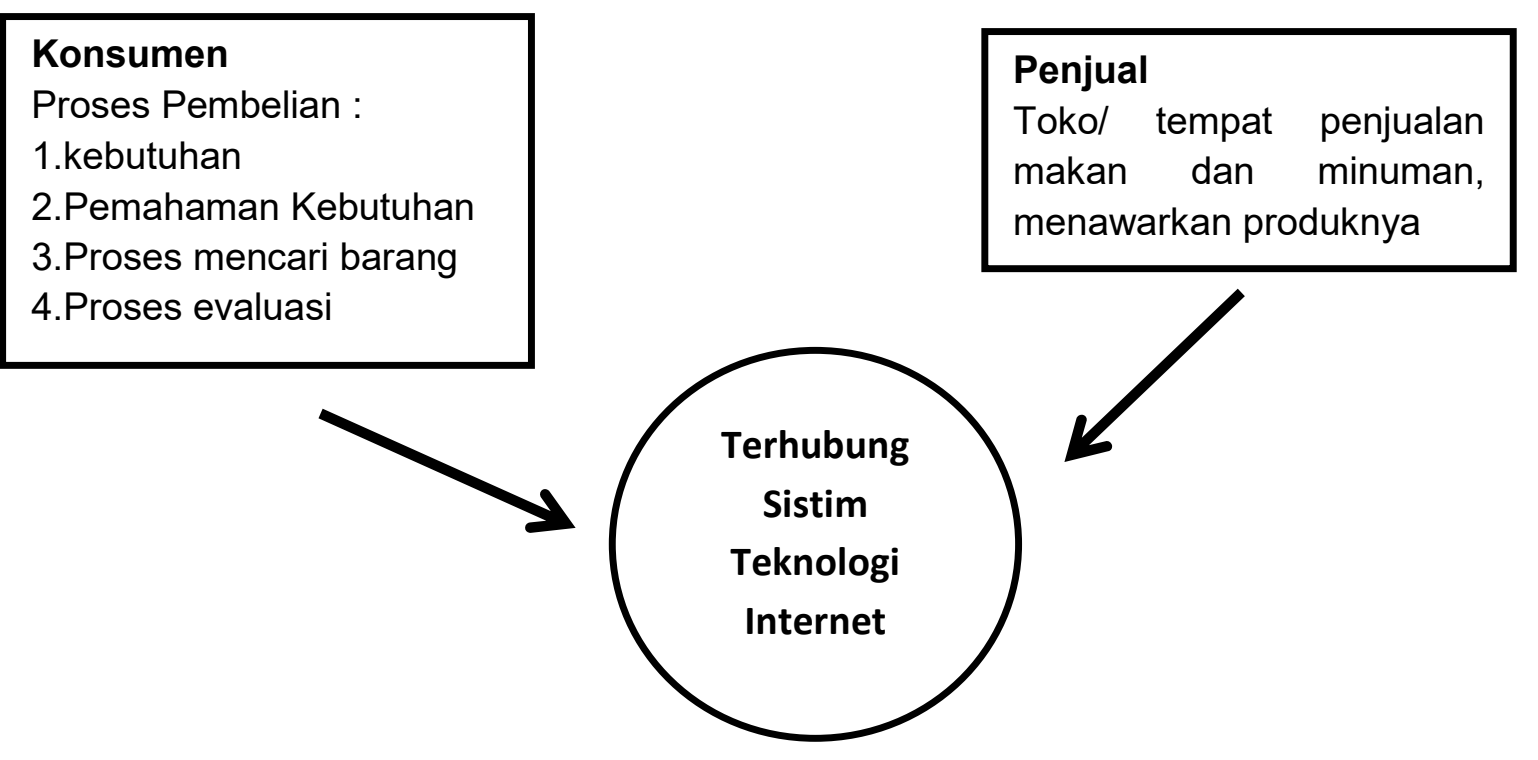

\begin{tabular}{|l|} 
Perbankan \\
Pembayaran melalui transfer : \\
ATM \\
Internet Banking \\
Phone Banking \\
Minimarket modern \\
\hline
\end{tabular}

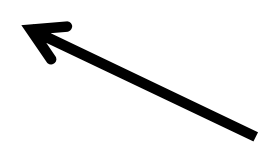
Kurir
Pengantar Barang
(ojek online)

\section{Kerangka Konsep Penelitian dan Hipotesis}

Dalam penelitian yang akan dilakukan peneliti menyusun kerangka konsep penelitian yaitu pengaruh kemudahan terhadap keputusan pembelian makanan secara online pada mahasiswa.

Kerangka konsep penelitian
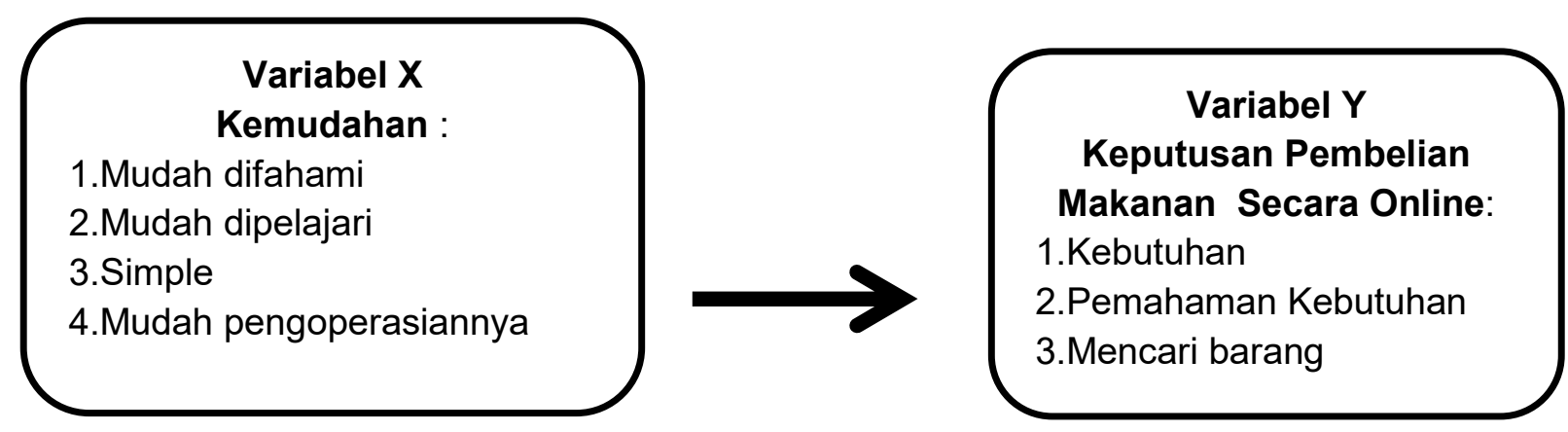
Rumusan Masalah/ Hipotesis

H0 : Tidak ada pengaruh kemudahan terhadap keputusan pembelian makanan secara online pada mahasiswa

H1 : Ada pengaruh kemudahan terhadap keputusan pembelian makanan secara online pada mahasiswa

\section{Pembahasan}

PopulasI dan Sample

Populasi mahasiswa Universitas Bina Sarana Informatika (UBSI) kampus Salemba 45 Jakarta berjumlah 950 mahasiswa.

\begin{tabular}{|c|c|c|}
\hline \multicolumn{1}{|c|}{ Jenis Kelamin } & Jumlah & Persentase \\
\hline Laki Laki & 578 & $60,84 \%$ \\
\hline Wanita & 372 & $39,16 \%$ \\
\hline Total & 950 & $100 \%$ \\
\hline
\end{tabular}

Sampel yang diambil menggunakan rumus slovin :

$$
\begin{aligned}
& \mathrm{n}=\frac{\mathrm{N}}{1+\mathrm{N} \cdot \mathrm{e}^{2}} \\
& \mathrm{n}=\text { Sample } \\
& \mathrm{N}=\text { Populasi } \\
& \mathrm{e}=\text { batas toleransi kesalahan } \\
& \mathrm{e}=10 \% \\
& \mathrm{n}=\frac{950}{\mathrm{+}}=950 \cdot(0,1)^{2}
\end{aligned}
$$


Uji Validitas

$\mathrm{df}=\mathrm{n}-2$

$\mathrm{df}=91-2$

$\mathrm{df}=89$

tingkat significant $=5 \%$

Maka di dapat $\mathrm{r}$ tabel $=0,2061$, bila $\mathrm{r}$ hitung $>\mathrm{r}$ tabel maka pernyataan dari kuesioner tersebut adalah valid.

Uji Validitas

Uji yang dilakukan untuk menunjukkan keabsahan instrumen penelitian. Menurut Arikunto (2006) validitas adalah suatu ukuran yang menunjukkan tingkat kevalidan dan kesahihan suatu instrumen.

Hasil Uji validitas variabel X variabel kemudahan dengan spss 19 :

Tabel Hasil Uji Validitas Variabel Kemudahan (X)

\begin{tabular}{|l|c|c|c|}
\hline & R hitung & R tabel & Keterangan \\
\hline Pernyataan1 & 0,2940 & 0,2061 & Valid \\
\hline Pernyataan2 & 0,3610 & 0,2061 & Valid \\
\hline Pernyataan3 & 0,3800 & 0,2061 & Valid \\
\hline Pernyataan4 & 0,3230 & 0,2061 & Valid \\
\hline
\end{tabular}

Hasil uji validitas variabel Y dengan spss 19 sebagai berikut :

Tabel Hasil Uji Validitas Variabel Keputusan Pembelian Secara Online (Y)

\begin{tabular}{|l|c|c|c|}
\hline & R hitung & R tabel & Keterangan \\
\hline Pernyataan1 & 0,2450 & 0,2061 & Valid \\
\hline Pernyataan2 & 0,2790 & 0,2061 & Valid \\
\hline Pernyataan3 & 0,2650 & 0,2061 & Valid \\
\hline Pernyataan4 & 0,2360 & 0,2061 & Valid \\
\hline
\end{tabular}


Uji Reliabilitas

Uji yang dilakukan untuk mengetahui ketepatan alat ukur penelitian (kuesioner) dalam mengukur gejala yang sama dan waktu yang berbeda. Menurut Sugiyono (2014) reliabilitas instrumen adalah suatu instrumen yang digunakan beberapa kali untuk mengukur obyek yang sama, maka akan mengahasilkan data yang sama. Hasil Uji Reliabilitas variabel X keputusan pembelian dengan spss 19 sebagai berikut :

\section{Case Processing Summary}

\begin{tabular}{|ll|r|r|}
\hline & & \multicolumn{1}{|c|}{$\mathrm{N}$} & \multicolumn{1}{|c|}{$\%$} \\
\hline Cases & Valid & 91 & 100,0 \\
& Excluded $^{\text {a }}$ & 0 &, 0 \\
& Total & 91 & 100,0 \\
\hline
\end{tabular}

a. Listwise deletion based on all variables in the procedure.

\section{Reliability Statistics}

\begin{tabular}{|r|r|}
\hline $\begin{array}{c}\text { Cronbach's } \\
\text { Alpha }\end{array}$ & $\begin{array}{c}\text { N of } \\
\text { Items }\end{array}$ \\
\hline, 612 & 4 \\
\hline
\end{tabular}

Variabel X Nilai cronbach alpha 0,612 maka dapat disimpulkan reliabel

Hasil uji Reliabilitas variabel Y dengan spss 19 adalah sebagai berikut:

Case Processing Summary

\begin{tabular}{|ll|r|r|}
\hline & & $\mathrm{N}$ & \multicolumn{1}{c|}{$\%$} \\
\hline Cases & Valid & 91 & 100,0 \\
& Excluded $^{\mathrm{a}}$ & 0 &, 0 \\
& Total & 91 & 100,0 \\
\hline
\end{tabular}

a. Listwise deletion based on all variables in the procedure.

\section{Reliability Statistics}




\begin{tabular}{|r|r|}
\hline $\begin{array}{c}\text { Cronbach's } \\
\text { Alpha }\end{array}$ & $\begin{array}{c}\text { N of } \\
\text { Items }\end{array}$ \\
\hline, 854 & 4 \\
\hline
\end{tabular}

Variabel Y Nilai cronbach alpha 0,854 maka dapat disimpulkan reliabel

Uji Regresi Linear Sederhana

Setelah melakukan uji regresi linear sederhana dengan spss19 didapat hasil sebagai berikut:

Model Summary

\begin{tabular}{|l|r|r|r|r|}
\hline Model & $\mathrm{R}$ & R Square & Adjusted R Square & $\begin{array}{c}\text { Std. Error of the } \\
\text { Estimate }\end{array}$ \\
\hline 1 &, $603^{\mathrm{a}}$ &, 364 &, 357 & 1,384 \\
\hline
\end{tabular}

a. Predictors: (Constant), Kemudahan

Besarnya nilai koefisien korelasi (R) dapat menunjukkan kekuatan pengaruh antara variabel X dan Y menurut sarwono (2006):

Nilai $\mathrm{R}=0 \quad$ artinya tidak ada korelasi antara dua variabel

$0,00 \mathrm{sd} 0,25$ artinya korelasi sangat lemah

0,25 sd 0,50 artinya korelasi cukup

$0,50 \mathrm{sd} 0,75$ artinya korelasi kuat

0,75 sd 0,99 artinya korelasi sangat kuat

Hasil uji regresi linear dengan spss19 didapat nilai R koefisien korelasi sebesar 0,603, artinya pengaruh variabel X Kemudahan terhadap variabel Y Keptusan Pembelian Secara Online adalah kuat. Dan Nilai Rsquare 0,364 artinya bahwa variabel X Kemudahan memiliki kontribusi mempengaruhi variabel Y Keputusan Pembelian Secara Online sebesar 36,40\% sisanya dipengaruhi oleh faktor faktor lain seperti kepercayaan, kualitas informasi, gaya hidup, dan lain lain. 
ANOVA

\begin{tabular}{|rl|r|r|r|r|r|}
\hline \multicolumn{2}{|l|}{ Model } & \multicolumn{1}{|c|}{$\begin{array}{c}\text { Sum of } \\
\text { Squares }\end{array}$} & \multicolumn{1}{c|}{ df } & \multicolumn{1}{c|}{$\begin{array}{c}\text { Sean } \\
\text { Square }\end{array}$} & F & \multicolumn{1}{c|}{ Sig. } \\
\hline 1 & Regression & 97,569 & 1 & 97,569 & 50,912 &, $000^{\mathrm{a}}$ \\
& Residual & 170,563 & 89 & 1,916 & & \\
& Total & 268,132 & 90 & & & \\
\hline
\end{tabular}

a. Predictors: (Constant), Kemudahan

b. Dependent Variable: Keputusan Pembelian

Hasil uji Anova siginificansi lineraitas (Sig) dengan syarat Sig $<0,05$ didapat hasil Sig 0,000, dengan $\mathrm{F}$ hitung 50,912 dengan demikian model persamaan regresi berdasarkan data penelitian adalah Signifikan.

\section{Coefficients $^{\mathrm{a}}$}

\begin{tabular}{|c|c|c|c|c|c|c|}
\hline \multirow{2}{*}{\multicolumn{2}{|c|}{ Model }} & \multicolumn{2}{|c|}{$\begin{array}{c}\text { Unstandardized } \\
\text { Coefficients }\end{array}$} & \multirow{2}{*}{$\begin{array}{c}\begin{array}{c}\text { Standardized } \\
\text { Coefficients }\end{array} \\
\text { Beta }\end{array}$} & \multirow[b]{2}{*}{$\mathrm{t}$} & \multirow[b]{2}{*}{ Sig. } \\
\hline & & B & Std. Error & & & \\
\hline \multirow[t]{2}{*}{1} & (Constant) & 4,515 & 1,954 & & 2,311 &, 023 \\
\hline & Kemudahan & ,788 &, 110 & 603 & 7,135 &, 000 \\
\hline
\end{tabular}

a. Dependent Variable: Keputusan Pembelian

Hasil perhitungan koefisien regresi sederhana di atas menyatakan nilai koefisien konstanta sebesar 4,515 dan variabel $\mathrm{X}$ adalah 0,788 sehingga diperoleh persamaan regresi sebagai berikut:

$$
\mathrm{Y}=0,788 \mathrm{X}+4,515
$$

Nilai posistif variabel $\mathrm{X}$ Kemudahan sebesar 0,788 dapat diartikan bahwa hubungan antara Kemudahan dan Keputusan Pembelian adalah searah. Dan setiap kenaikan satu satuan variabel akan menyebabkan kenaikan kemudahan 0,788.

Hasil Uji t merupakan uji atas hipotesis nol (H0), apabila nilai uji $\mathrm{t}>\mathrm{t}$ Tabel maka hipotesi nol (H0) ditolak dan $\mathrm{H} 1$ diterima. Nilai t hitung adalah 7,135 dengan nilai signifikansi 0,000 dimana nilai t Tabel dengan $\mathrm{df}=\mathrm{n}-\mathrm{k}$ atau $\mathrm{df}=91$ $2, \mathrm{df}=89$ dengan signifikansi 0,05 nilai t Tabelnya adalah 1,98698. Maka 7,135 $>$ 1,98698 berarti H0 ditolak dan H1 diterima artinya Ada pengaruh kemudahan terhadap keputusan pembelian makanan secara online pada mahasiswa. 


\section{Penutup}

Berdasarkan pembahasan diatas dapat disimpulkan bahwa faktor kemudahan menurut hasil uji t dengan spss19, nilai t hitung adalah 7,135 dengan nilai signifikansi 0,000 dimana nilai t tabel dengan signifikansi 0,05 nilai t Tabelnya adalah 1,98698. Maka nilai t hitung 7,135 > 1,98698 nilai t Tabel, berarti hipotesi Nol (H0) ditolak dan H1 diterima artinya Ada pengaruh kemudahan terhadap keputusan pembelian makanan secara online pada mahasiswa. Hasil uji regresi linear didapat nilai $\mathrm{R}$ (koefisien korelasi) sebesar 0,603, artinya pengaruh variabel X Kemudahan terhadap variabel Y Keptusan Pembelian Secara Online adalah kuat. Dan juga didapat nilai R square 0,364 artinya bahwa variabel X Kemudahan memiliki kontribusi mempengaruhi variabel Y Keputusan Pembelian Secara Online sebesar $36,40 \%$ sisanya dipengaruhi oleh faktor faktor lain seperti kepercayaan, kualitas informasi, gaya hidup, dan lain lain.

\section{DAFTAR PUSTAKA}

Arikunto, S. 2006.Meode Penelitian Kuantitatif.Jakarta: Bumi Aksara.

Howar, JA. And Shay,R.P 1988. Measuring The effect of Marketing Information on Buying Intention. The Journal of Service Marketing. Vol.2., No.4 Fall, P.27-36.

https://inet.detik.com/telecommunication/d-3808941/apjii-internet-semakinmurah-pengguna-terus-bertambah

Jogiyanto, 2007.Sistim Informasi Keperilakuan.Edisi revisi.Yogyakarta: Andi offset

Kottler, Amstrong, 2001. Prinsip-prinsip pemasaran. Edisi keduabelas, Jilid 1. Jakarta : Erlangga.

M.Mujiyanan dan I. Elissa, 2013. Analisis Faktor-faktor yang mempengaruhi Keputusan Pembelian via Internet Pada Toko Online. Jurnal Teknik Industri, Vol.8, No.3, pp.143-152, https://doi.org/10.12777/jati.8.3.143152

Sarwono, 2006. Metode Penelitian Kuantitatif dan Kualitatif. Yogyakarta: Graha Ilmu 
Siswoyo, Dwi, dkk. 2007. Ilmu Pendidikan. Yogyakarta: UNY Press

Sugiyono, 2014. Metode Penelitian Pendidikan Pendekatanan Kuantitatif, Kualitatif, dan R\&D. Bandung: Alfabeta.

.Sumarwan, Ujang, 2003. Perilaku Konsumen. Bogor: PT. Ghalia.

Wardoyo dan Intan andini, 2017. Faktor-faktor yang Berpengaruh terhadap Keputusan Pembelian Secara Online Pada Mahasiswa Universitas Gunadarma. Jurnal Manajemen Dayasaing, Vol.19, No.1,pp.12-26, http://journals.ums.ac.id/index.php/dayasaing/article/view/5101 